\author{
A.V. Ubaychin ${ }^{1}$, A.P. Surzhikov ${ }^{1}$, O. Starý ${ }^{2}$, A.K. Khassenov ${ }^{3}$, D.Zh. Karabekova ${ }^{3}$ \\ ${ }^{I}$ Tomsk Polytechnic University, Russia; \\ ${ }^{2}$ Czech Technical University in Prague, Czech Republic; \\ ${ }^{3}$ Ye.A. Buketov Karaganda State University, Kazakhstan \\ (E-mail:ubaychin@tpu.ru)
}

\title{
Laboratory model of microwave hyperspectrometer for internal radiation researches of layered natural mediums
}

\begin{abstract}
This paper describes an achieved result in designing of the four-receiver microwave hyperspectrometer based on zero measurement method and the multi-receiver concept of realization. The block diagrams of the microwave front-end with operating frequency band from 18 to $26.5 \mathrm{GHz}$, the radiometric receiver, and the frequency transmission module are shown. The technical implementation of every described blocks of the microwave hyperspectrometer are described. Presented technical implementation includes a list of modern components are used to designing of laboratory model of hyperspectrometer. The detailed block diagram of the microwave front-end is presented. Description of main technical characteristics of parts of the microwave front-end is also presented. The analysis of a technical characteristics influence to measurement errors is shown. The mathematical model of a measurement error calculation in hyperspectral modeis described. The influence of the active reference noise generator temperature accuracy, the directional coupler insertion loss and the passive reference noise generator temperature accuracy to a measurement errors are described. A numerical experimental results of designed mathematical model are presented. The dependence of the minimum value of measurement errors form the temperature of passive noise generator is presented.
\end{abstract}

Keywords: microwave hyperspectral measurements, new measurements methods, scientific instrumentation, zero measurements method, measurements at microwave.

\section{Introduction}

The climate change issue on our planet goes back to the Middle Ages. Even in the middle of the twentieth century, the climate change dynamics causes concern, but the reality of serious changes could only be assessed by experts. Today, every resident of our planet can observe the following changes: rivers dry up, the fresh water glacier stocks area decreases, the climate zones of permafrost shift, the annual average temperature increases, etc.[1].

One of the important factors, which affects the dynamics of the climate evolution is the interaction of the World Ocean and the atmosphere. The interaction of heat fluxes and evaporated moisture over the World Ocean largely determines climate-forming factors. Global and continuous monitoring of the interaction would make it possible to enhance the accuracy of dynamic ocean-atmosphere models and provide more accurate results not only in the short term prediction, but also create a long-term forecast of the dynamics of such changes $[2,3]$.

A high-qualitydetailed solution of the inverse problemsof analysis of the state of wind speed, the moisture zones and the intensity of precipitation, the moisture content of the atmosphere, the water content of clouds can improve the climate prediction. A qualitative improvement in detail, in a broad sense, is possible due to an increase in the informativeness of the remote sensing methods $[4,5]$.

There is widespread ofthe passive methods for the atmosphere remote sensing. The study of the absorption rate of water vapors allows to solve wide range of scientific and applied problems.

Steadily growing needs in research results necessitated the development of the microwave hyperspectrometer to capture a wide spectrum range and obtain reliable information about atmosphere condition. Along with the spectrum expansion, there is a problem of increasing the number of spectral lines in the studied range. In this regard, there were several research studies that showed the possibility ofincreasing the spectral resolution, while maintaining both desired sensitivity and measurement duration. This approach is based on the use of the zero measurement method and the multi-receiver principle.

This paper describes an approach for the laboratory model implementation of the microwave hyperspectrometer to study the absorption line of water vapor at a frequency of $22 \mathrm{GHz}$. 


\section{Block diagram of microwave hyperspectrometer}

As demonstrated in [6], the frequency resolution in the multi-receiver microwave hyperspectrometer is proportional to the number of receivers in the hyperspectrometer. The number of receiversis set while designing and depends on the desired frequency resolution and the fluctuation sensitivity. However, from a technical standpoint, the number of receiver is limited by the configuration of the input microwave switch. Currently, the microwave switches in two and four throw are produced by a wide spectrum of companies. More complex configurations of solid-state microwave switches are either less complex configuration or customized hybrid. From the technical standpoint, the laboratory model is most convenient with four receivers.

Figure 1 shows the block diagram of the laboratory model of the microwave hyperspectrometer developed in accordance with an approach described in [6].

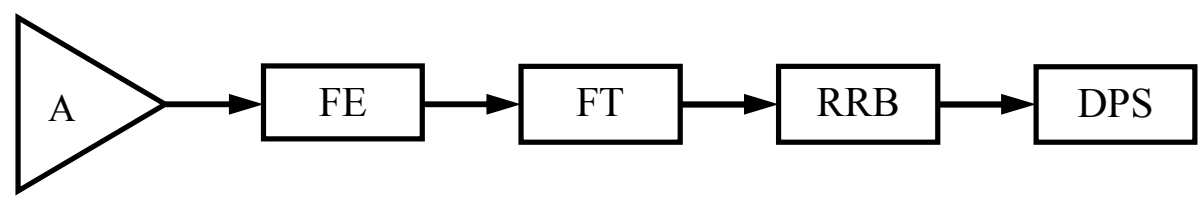

Figure1. Block diagram of the laboratory model of the microwave hyperspectrometer

The block diagram shown in Figure 1 consists of an antenna - A, a microwave front-end - FE, a frequency selection and translation module $-\mathrm{TF}$, a radiometric receivers module - RRB and a digital processing system - DPS. A standard waveguide antenna PE9852-20 with frequency range from 18 to $26.5 \mathrm{GHz}$ and nominal directive gain $20 \mathrm{~dB}$ is used as an antenna of the laboratory model. The microwave front-end is made in accordance with block diagram shown in Figure 2.

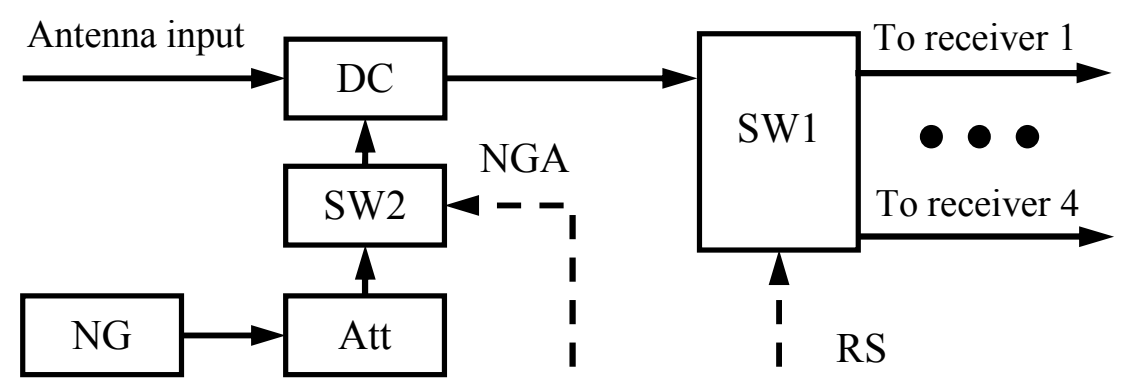

Figure 2. Block diagram of the microwave front-end of the hyperspectrometer

The microwave front-end includes a directional coupler - DC, a first microwave absorption type switch with a one pole to four throw configuration - SW1, a second microwave absorption type switch with one pole to one throw configuration - SW2, anattenuator - Att and a noise generator - NG.

The microwave front-end is designed to alternately switch the antenna input to every receiver. The alternate switching is controlled by receiver selection signal (RS). The signal of the noise generator is transmitted to the input of the first microwave switch through a directional coupler. The power of the noise generator signal is regulated by the attenuator. The duration of the noise generator signal is regulated by the second microwave switch. It is controlled by a pulse-width modulated signal (NGA). The operation algorithm of the multi-receiver microwave hyperspectrometer is well discussed in [6, 7].

The directional coupler in the Figure 2 based on the edge coupled microstrip transmission line. The estimated coupling factor is minus $25 \mathrm{~dB}$ with a directivity of $23 \mathrm{~dB}$. The first microwave switch is implemented on the ADRF5045 microchip. The second microwave switch is implemented on the HMC547 microchip. The digital attenuator ADRF5730 is used to control the power of noise generator, which implemented on avalanche and transit-time diode $\mathrm{NC} 403 \mathrm{CH} 3$.

The frequency transmission module is used for the implementation of the frequency conversion. Thefrequency transmission module provides serial operations of amplification, allocation of the operating frequency band, frequency down conversion and phase suppression of the mirror channel.

The configuration of the second microwave switch allows the input of each receiver to be switched either to an antenna or to an internally matched load. It allows to implement the differential measurement 
method and remove the influence of the slowly changing receiver noise temperature on the measurement results.

As shown in [8-10], the differential method and its technical implementation in the tasks of passive remote sensing do not allow to remove the influence of receiver gain changes. In order to remove these effects, the special mode of the differential measurement method - zero measurement method is used. It should be noted that zero measurement method also removesthe influence of $1 / f$ noises [11].

Using of the zero measurement method involves the transfer characteristic based on two reference points specified by reference noise generators [12]. In the presented technical implementation, the first passive generator is matched load with noise temperature close to its physical temperature. The second reference noise generator based on the avalanche diode. The power level of the second noise generator provides the location of the second reference point of the transfer characteristic and determines the value of dynamic range value of measured antennas noise temperature. The stability of the reference noise generators mainly defines the whole system accuracy $[13,14]$.

The presented microwave hyperspectrometer uses receivers with frequency transmission. It is necessary to increase the frequency selectivity and the comparatively simple frequency adjustment. For its implementation frequency transmission module is designed. The block diagram of the frequency transmission module is presented in Figure 3.

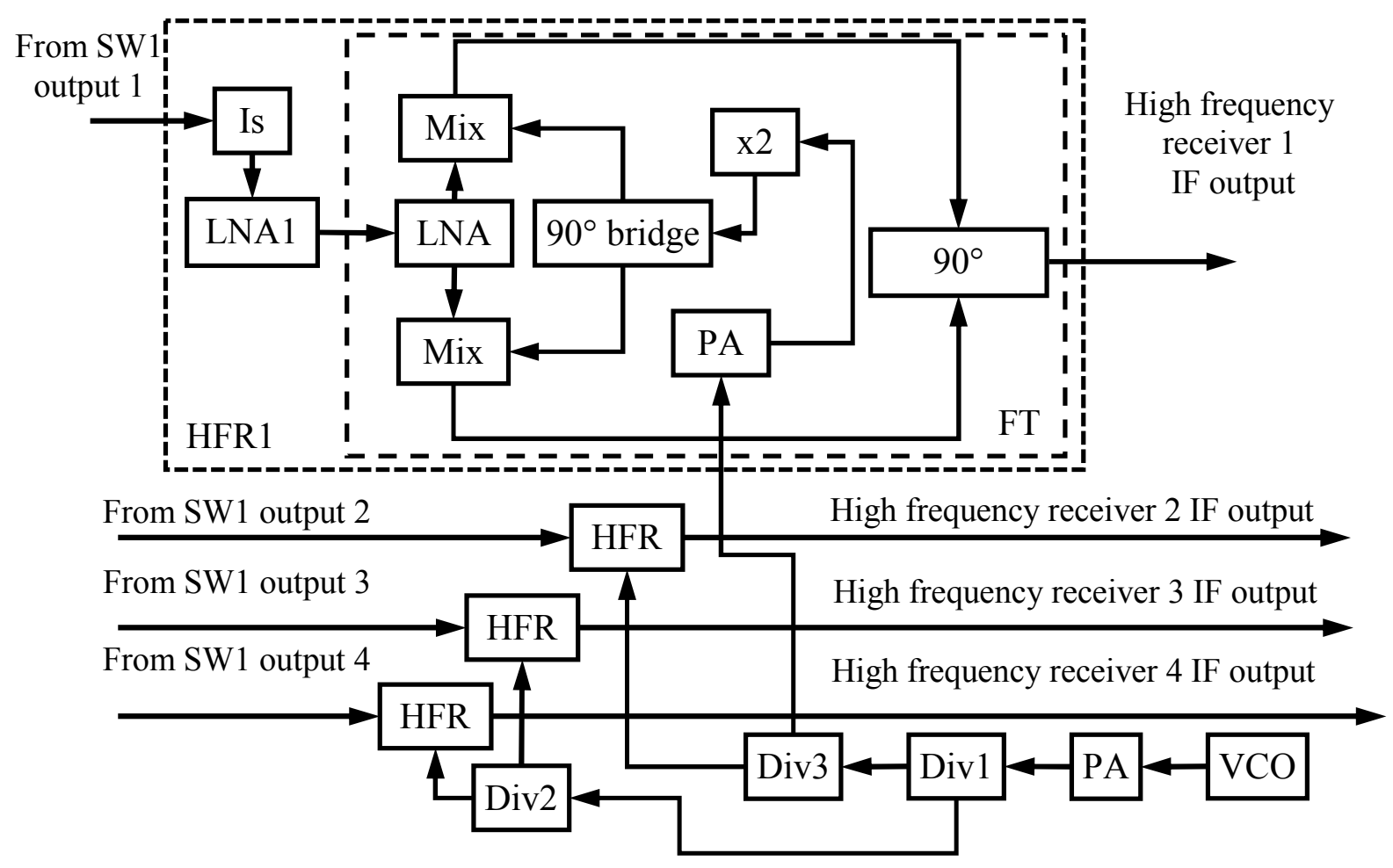

Figure 3. Block diagram of the frequency transmission module

The frequency transmission module consists of four identical in structure microwave parts of the high frequency receivers (HFR1, ..., HFR4), three microwave dividers (Div1, Div2, Div3), a power amplifier (PA) and a voltage control oscillator (VCO). Each microwave receiver consists of an isolator (Is), a first low noise amplifier (LNA1), a frequency transmission module (FT) and a 90 -degree hybrid coupler $\left(90^{\circ}\right.$ bridge). The frequency transmission module consists of a second low noise amplifier (LNA2), two mixers, a 90 hybrid coupler $\left(90^{\circ}\right.$ bridge), a multiplier $(\times 2)$ and a power amplifier of a heterodyne signal. The heterodyne signal is transmitted to the power amplifier input. The heterodyne signal tentatively amplified in the power amplifier and then equally divided between the four receivers. The division is carried out in series connected power dividers.

The frequency transmission module performs phase suppression of the mirror channel by using the 90-degree hybrid couplers, that ensures phase shift $180^{\circ}$ for mirror channel components. It provides additional possibility of frequency scanning for measuring the intensity of absorption in a wider frequency spec- 
trum [15]. The use of a frequency multiplier reduces the requirements for frequency range of a voltage controlled oscillator.

The edge wave ferrite device FPVN2-302is used as the microwave isolator, the first low noise amplifier is implemented on the HMC751 microchip, the mixer with the phase suppression is implemented on the HMC977 microchip, the 90-degree hybrid couplers is based on the LTCC transformer. The heterodyne is implemented on the HMC6380 microchip, the heterodyne signal amplifier is implemented on the HMC541 microchip, the power dividers implemented on the EP2K.

The presented configuration of the technical implementation of the frequency transmission module provides an operating frequency band from $18 \mathrm{GHz}$ to $28 \mathrm{GHz}$. The intermediate frequency range is $0 \ldots 3.5 \mathrm{GHz}$. The gain in operating frequency range is at least $34 \mathrm{~dB}$. The use of the voltage control oscillator allows the adjustment of the operating frequency range. Based on the technical description of the mixer, the up side band is chosen.

As stated earlier, the gain of the amplification frequency transmission module is not enough to achieve the required level at the ADC input. It is also necessary to increase selectivity in the operating frequency range, and therefore there is a need for the use of additional amplifiers in the intermediate frequency channel [16]. The intermediate frequency channel is implemented as a radiometric receivers module. Figure 4 shows the block diagram of the intermediate frequency receivers module as part of the radiometric receivers module.
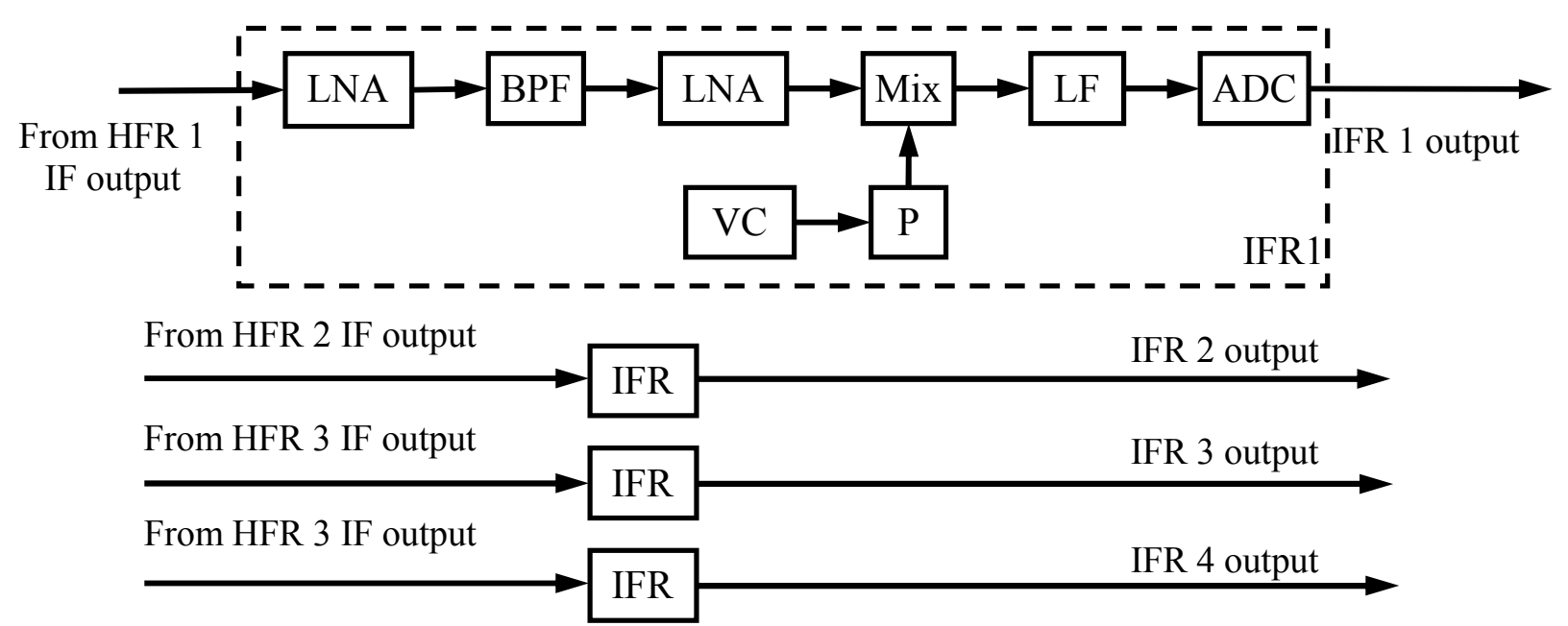

Figure 4. Block diagram of the radiometric receivers module

The radiometric receivers module consists of four identical in structure intermediate frequency receivers (IFR1, IFR2, IFR3, IFR4). Each module consists of a series connected first low noise amplifier (LNA1), a band pass filter (BPF), a second low noise amplifier (LNA2), a balance mixer (Mix), a low-pass filter (LPF), and an analog-to-digital converter (ADC). The voltage control oscillator is connected to heterodyne input of mixer though the power amplifier.

The intermediate frequency module provides an amplification of a signal of the intermediate frequency module of the corresponding microwave receiver, a frequency discrimination, a frequency conversion, a frequency scanning and digitizing of measurement result.

The band pass filter is used to achieve an operating frequency band (mirror channel suppression). In comparison with typical solutions, which are based on phase suppression, the band pass filter provides an increase in suppression of the mirror channel to $10 \ldots 30 \mathrm{~dB}$. Suppression of heterodyne signal may be required in implementing this low-pass filter. In this case, low-pass filters manufactured by industry are very useful. In addition, a low-pass filter with a cutoff frequency exceeding the operating frequency by $3 \ldots 7$ octaves are used to suppress the heterodyne signal. In the operating frequency band of the filter, additional filtering occurs with a second low-pass filter, the band of which corresponds to the required operating frequency band.

In the intermediate frequency receivers module both the first and the second low noise amplifier and the power amplifier are based on the GVA-63 microchip. The mixer is implemented on the HMC219 microchip, the low-pass filter is made on the LTCC technology and presented as the LFCN-225, the analog-to-digital 
converter is developed on the LTC2252. The band pass filter is based on the coupled microstrip U-shape resonators with capacitive broadening at the at the edges. The five resonators filter provides intermediate frequency band about $300 \mathrm{MHz}$.

To manage the entire hyperspectral system, a digital processing module is used. The digital processing module generates pulse-width and amplitude-pulse modulation signals. The module controls the operation modes of ADC and etc. [17]. The measurement results come from the outputs of the radiometric receiver module to the system input. In accordance with the algorithm described in [16], after processing the measurement result of the reference noise generators levels, the NGA signal is generated with the specified duration for each receiver.

\section{Measurement errors analysis}

In practice, changes in external operating conditions, primarily temperature, leads to the measurement errors, caused by the imperfection of the microwave front-end. Figure 5 shows the block diagram of the microwave front-end, taking into account its own imperfection.

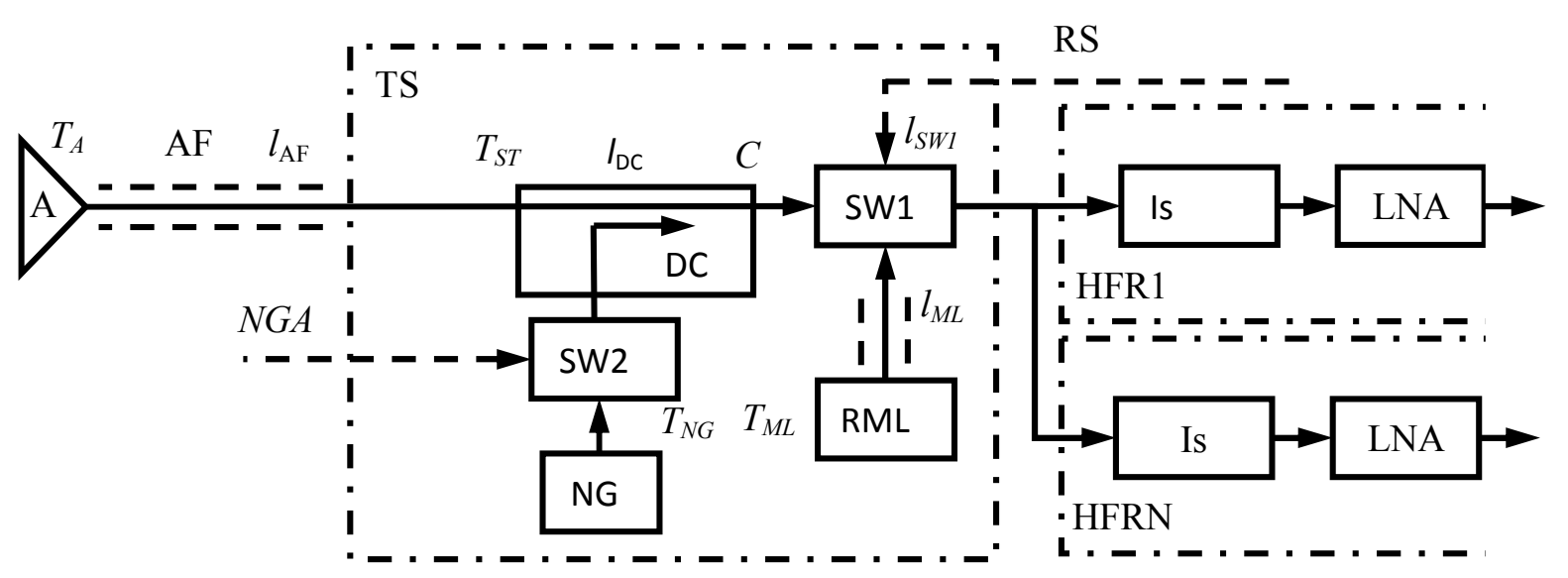

Figure 5. Block diagram of the microwave front-end taking into disadvantages

The block diagram of the microwave front-end consists of an antenna A with a noise temperature $T_{A}$, an antenna feeder AF with insertion loss $l_{A F}$, a directional coupler DC with insertion loss $l_{D C}$ and a coupling factor C, a first microwave switch SW1 with insertion loss $l_{S W}$, a reference matched load RML with noise temperature $T_{M L}$, a matched load feeder FML with noise temperature $T_{M L}$, a second microwave switch SW2, an active noise generator NG with noise temperature $T_{N G}$, a thermostat TS with temperature $T_{S T}$, a part of radiometric receiver RR which consists of a low noise amplifier LNA, a band pass filter BPF, a wide band amplifier WBA.

In Figure 9, the radiometric receiver parameters (gain, own noises, etc.) are not shown, since the influence of its changes is removed by the zero measurement method. To control the impact of the input loss of the microwave front-end, all passive elements areplaced in thermostat with constant temperature and specified accuracy [18-20]. The impact of losses in antenna feeder is not taken into account, since it cannot be controlled with a hyperspectrometer [21].

To estimate the measurement error of the microwave hyperspectrometer based on the zero measurement method, the mathematical model for estimating the measurement errors in the microwave front-end is developed. The mathematical model describing the errors of the hyperspectrometer based on the zero measurement method is described by the expression:

$$
d T_{A}=d T_{M L}-\left\langle\frac{C \cdot d T_{N G} \cdot N G A}{R S \cdot\left(1-l_{D C}\right)}\right\rangle,
$$

where $d T_{M L}$ is accuracy of the passive reference noise generator temperature (matched load), $N G A / R S$ is width and amplitude pulse modulations ratio, $l_{D C}$ is value of insertion loss in directional coupler, $d T_{N G}$ is an accuracy of active reference noise generator temperature.

In accordance with the zero measurement method implementation, the antenna noise temperature is lineary related to the duration of the pulse-width modulated signal [16]. Therefore, the $d T_{A}$ value in (1) is a function including the measured noise temperature of the antenna, which sets the $N G A / R S$ ratio. 


$$
N G A=R S \cdot\left(T_{M L}-T_{A}\right) / T_{N G},
$$

where $T_{A}$ is antenna noise temperature, $T_{M L}$ is matched load noise temperature, $T_{N G}$ is noise generator temperature. The expression (2) provides an estimate of the $N G A / R S$ ratio when the antenna noise temperature is specified.

The expression (1) does not include noises caused by insertion attenuation in the reference matched load feeder. This fact is due to the thermodynamics equilibrium of the feeder noise and the reference matched load, if their physical temperature is equal.

The noises caused by the insertion loss of the microwave switch also are not included in the expression (1). This effect caused by the implementation of the differential measurement method and the equality of insertion loss between both directions of the microwave switch [22]. If the last condition is not met, then noise loss accounting is required.

To simplify the calculations and in the absence of control possibilities, the expression (1) does not include the noises of the antenna feeder. The analysis shows that the physical temperature of the antenna feeder during operation of the microwave hyperspectrometer in harsh climates varies by tens and hundreds of degrees. With such temperature changes, the minimal insertion losses in the antenna feeder lead to the changes in the measured noise temperature. The measurement instability caused by insertion losses in the antenna feeder is several times higher than the instability of the noise generator and thermostat temperature accuracy.

To estimate the measurement error, the simulation of the microwave hyperspectrometer operation is performed $[23,24]$. The simulation results are obtained for given typical parameters of the microwave frontend: thermostat temperature accuracy is $\pm 1 \mathrm{~K}$, dynamic range value of measured antennas noise temperature is $0 \ldots 300 \mathrm{~K}$, value of insertion loss of directional coupler is 0.01 to 0.2 , accuracy of active reference noise generator temperature is $\pm 1,5 \mathrm{~K}$. The results of modeling the measurement error of the microwave hyperspectrometer taking into account various parameters are presented in Figure 6.

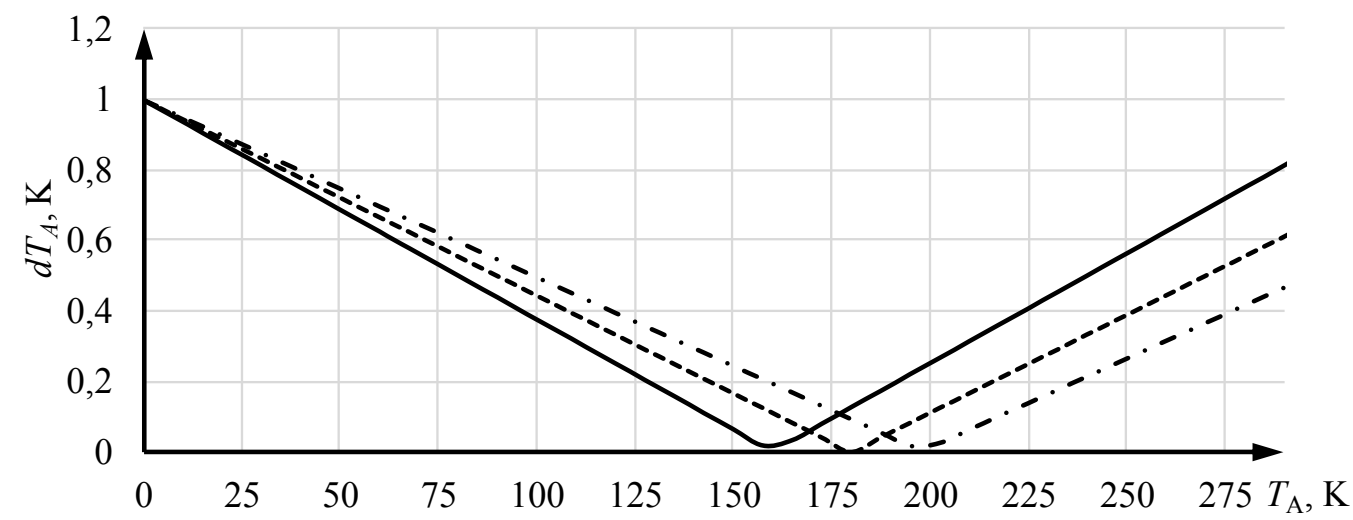

Figure 6. Module of the microwave hyperspectrometer errors

In Figure 6 solid, dash and dash-dot lines corresponds to the attenuator insertion loss values equal to $0.01,0.1$ and 0.2, respectively. The analysis of the simulation results shown in Figure 6 allows to conclude about the following. At the lower boundary of the dynamic range, the value of measurement error is determined by the accuracy of the thermostat. At the upper boundary, the value of measurement error is equal to the difference of passive and active noise generators accuracy modulus.

The accuracy of both passive and active noise generators determines the value of the antenna noise temperature at which the measurement results have a minimum error. The changes of insertion loss value in the directional coupler has little impact on the resulting measurement accuracy [25]. The error in maintaining the temperature of the passive noise generator most affectsthe resulting measurement accuracy. The use of the active semiconductor low-temperature noise generators is the most acceptable way to fix or reduce it.

When reducing the impact of losses in the antenna feeder, the most appropriate way is to control the temperature of the antenna feeder with specified insertion loss value. This approach complicates the hyperspectral system and does not take into account changes in antenna feeder insertion loss over time. 


\section{Conclusion}

The technical implementation of laboratory model of the microwave hyperspectrometer based on the zero measurement method and the multi-receiver concepts is designed. The designed block diagram describes the variants for a specific implementation on the industry produced electronic components. The used components allow to implement the operating frequency band from 18 to $26.5 \mathrm{GHz}$. The applied approach of filtering and phase suppression method of the mirror channel allows to achieve the operating frequency band of about $225 \mathrm{MHz}$.

The designed detailed block diagram allows to estimate the measurement error as a function of the parameters both the microwave front-end and the receiver.

In the further development of the presented results, it is planned to conduct a series of laboratory tests to estimate the fluctuation sensitivity with specified frequency resolution. 00045).

The conducted research is supported by a grant of the Russian Science Foundation (project № 18-79-

\section{References}

1 Blume, C., Kendall, B., \& Fedors, J. (1978). Measurement of ocean temperature and salinity via microwave radiometry. Boun. Layer Met., 134, 95-308.

2 Karvonen, J. (2017). Baltic Sea Ice Concentration Estimation Using SENTINEL-1 SAR and AMSR2 Microwave Radiometer Data. IEEE Trans. on Geosc. and Rem. Sens., 99, 1-3.

3 Tanner, A. (1998). Development of a high-stability water vapor radiometer. Radio Sci., 33, 449-462.

4 Tanner, A., \& Riley, A. (2003). Design and performance of a high-stability water vapor radiometer. Radio Sci., $38,1-11$. 98.

5 Harvey, A., \& Appleby, R. (2003). Passive mm-wave imaging from UAVs using aperture synthesis. Aeronaut. J., 107, 87-

6 Ubaichin, A., \& Surzhikov, A. (2019). Dynamics of internal thermal processes in dielectric materials and the method of its measurement in microwave hyperspectral mode. Mat. Sci. For., 942, 151-161.

7 Filatov, A., \& Ubaichin, A. (2012). A microwave four-channel null L-band radiometer, Instr. and Exp. Tech., 55, 59-64.

8 Dicke, R. (1946). The measurement of thermal radiation at microwave frequencies, Rev. Sci. Instr., 17, $268-275$.

9 Orhaug, T. (1962). Switched load radiometer. Publ. Nat. Radio Astron. Obs., 1, 179-204.

10 Corbella, I. (2005). Analysis of correlation and total power radiometer front-ends using noise waves. IEEE Trans. on Geosc. and Rem. Sens., 43, 2452-2459.

11 Filatov, A., \& Ubaichin, A. (2012). The dynamic properties of a digital radiometer system and its operating efficiency. Meas. Tech., 54, 1-5.

12 Camps, A. (2010). Noise wave analysis of Dicke and noise injection radiometers: Complete S parameter analysis and effect of temperature gradients. Radio Science., 45, 649-652.

13 Frater, R., \& Williams, D. (1981). An active «cold» noise source. IEEE Trans. on Micr. Theory and Tech., 29(4), $344-347$.

14 Allan, D. (1987). Time and frequency characterization, estimation, and prediction of precision clocks and oscillators. IEEE Trans. Ultrason. Ferroelectr., 6, 647-654.

15 Blackwell, W., Leslie, V., Pieper, M., \& Samra, J. (2010). All-weather hyperspectral atmospheric sounding. Lincoln lab. J., $18,28-46$.

16 Filatov, A., \& Ubaichin, A. (2013). A two-receiver microwave radiometer with high transfer characteristic linearity. Meas. Tech., 55(11), 1281-1286.

17 Fischman, M., \& England, A. (1999). Sensitivity of a $1.4 \mathrm{GHz}$ direct-sampling digital radiometer. IEEE Trans. on Geosc. and Rem. Sens., 37(5), 2172-2180.

18 Han, Y., \& Westwater, E. (2000). Analysis and improvement of tipping calibration for ground-based microwave radiometers. IEEE Trans. on Geosc.and Rem. Sens., 38, 1260-1277.

19 He, H., Chen, T., \& Chen, M. (2019). Remote sensing image super-resolution using deep-shallow cascaded convolutional neural networks. Sens. Rev., 39(5), 629-635.

20 Nussupbekov, B.R., Kartbaeva, G.T., Stoev, M., Khassenov, A.K., Karabekova, D.Zh., \& Muratova, A.K. (2019). Electrohydroimpulse method of extracting bone grease. Bulletin of the Karaganda University. Physics series, 2(94), 101-107, doi: 10.31489/2019Ph2/101-107.

21 Hersman, M., \& Poe, G. (1981). Sensitivity of the total power radiometer with periodic absolute calibration. IEEE Trans. on Micr. Theory and Tech., 29(1), 32-40.

22 Kaisti, M., Altti, M., \& Poutanen, T. (2016). Radiometric resolution analysis and a simulation model. Rem. Sens., 8(85), 1-9.

23 Kerr, Y., \& Waldteufel, P. (2001). Soil moisture retrieval from space: The soil moisture and ocean salinity mission. IEEE Trans. on Geosc. and Rem. Sens., 39, 1729-1735.

24 Kucheruk, V.Yu., Kurytnik, I.P., Oshanov, Ye.Z., Kulakov, P.I., Semenov, A.A., Karabekova, D. Zh. et al. (2019). Computer-measuring system of the induction motor's dynamical torque-speed characteristics. Bulletin of the Karaganda University. Physics series, 2(94), 92-100. 
25 Bemš, J., Starý, O., Macaš, M., Žegklitz, J., \& Pošík, P. (2015). Innovative default prediction approach. Expert Systems with Applications, 42, 17-18, 6277-6285.

\author{
А.В. Убайчин, А.П. Суржиков, О. Стары, А.К. Хасенов, Д.Ж. Карабекова
}

\title{
Қабатты табиғи ортадалардың өзіндік электромагниттік сәулеленуін зерттеуге арналған асажоғарыжиілікті гиперспектрометрдің зертханалық макеті
}

\begin{abstract}
Мақалада нөлдік өлшеу әдісі және төрт қабылдағышты қамтитын көпқабылдағыш принципі негізінде жаңа жоғары жиілікті гиперспектрометрді іске асыру кезінде алынған нәтижелер келтірілген. 18-ден 26,5 ГГц-ке дейінгі жұмыс жиіліктерінің диапазоны бар жоғары жиілікті кіріс бөлігінің, радиометриялық қабылдағыш пен жиілікті тасымалдау блогының құрылымдық сұлбасы ұсынылған. Жоғары жиілікті гиперспектрометрдің сипатталған блоктарының әрқайсысын тәжірибелік іске асыру әдісі келтірілген. Техникалық іске асыру ұсынылған әрбір блоктар мен гиперспектрометр модульдері үшін элементтік база тізбесі түрінде берілген. Жоғары жиілікті гиперспектрометрдің кіріс бөлігінің егжей-тегжейлі құрылымдық сұлбасы көрсетілген. Егжей-тегжейлі құрылымдық диаграмманың әрқайсысының негізгі техникалық сипаттамалары берілген. Әрбір бөліктері көрсетілген құрылымдық сұлбаның жекеленген блоктарының негізгі техникалық сипаттамаларының талдаулары, сонымен қатар жоғары жиілікті кіріс бөлігінің блоктары сипаттамаларының өлшеу қателігіне әсері туралы мәліметтер келтірілген. Гиперспектральді режимде өлшеу қателігін бағалауға арналған математикалық модель ұсынылған. Шудың белсенді тірек генераторының шулы температурасын сүйемелдеу дәлдігінің әсері, тармақтағыштың бағыты мен пассивті тірек генератордың шулы температурасын ұстап тұру дәлдігінің өлшеу нәтижелеріне әсері көрсетілген.
\end{abstract}

Кілт сөздер: асажоғарыжиілікті гиперспетрометр, жаңа өлшем әдістері, ғылыми аспап жасау, нөлдік өлшем әдісі, жоғары жиілікті диапазонда өлшеу.

\author{
А.В. Убайчин, А.П. Суржиков, О. Стары, А.К. Хасенов, Д.Ж. Карабекова
}

\section{Лабораторный макет сверхвысокочастотного гиперспектрометра для исследования собственного электромагнитного излучения слоистых природных сред}

\begin{abstract}
В статье приведены результаты при реализации нового сверхвысокочастотного гиперспектрометра на основе метода нулевых измерений и принципа многоприемниковости, включающего в себя четыре приемника. Представлены структурные схемы входной сверхвысокочастотной части с диапазоном рабочих частот от 18 до 26,5 ГГц, радиометрического приемника и блока переноса частоты. Приведен способ практической реализации каждого из описанных блоков сверхвысокочастотного гиперспектрометра. Техническая реализация представлена в виде перечня элементной базы для каждого из блоков и модулей гиперспектрометра. Показана детализированная структурная схема входной сверхвысокочастотной части гиперспектрометра. Описаны основные технические характеристики каждого из блоков детализированной структурной схемы, а также данные анализа влияния характеристик блоков входной высокочастотной части на погрешность измерений. Предложена математическая модель для оценки погрешности измерений в гиперспектральном режиме. Показано влияние точности поддержания шумовой температуры активного опорного генератора шума, потерь в направленном ответвителе и точности поддержания шумовой температуры пассивного опорного генератора на результаты измерений.
\end{abstract}

Ключевые слова: сверхвысокочастотный гиперспектрометр, новые методы измерений, научное приборостроение, нулевой метод измерений, измерения в сверхвысокочастотном диапазоне. 